days. Leachings were made by allowing the ground rock to remain in an iron tank containing hot water. After one hour the leachings were drawn off and the partial analysis made on this solution is shown in column I. Fresh hot water was then added and allowed to remain twenty four hours and this repeated for eleven days. Column II represents the partial analysis of the solution obtained after one day in contact with the ground rock following the one-hour extraction, column III, that on the fourth day and IV, the eleventh day. Constituents are given in percentages in solids obtained from leaching waters and grams of solids per roo cc. of solution are shown at the bottom. The first leaching was neutral to litmus and all the rest were decidedly alkaline.

Leaching with cold water was also tried but the experiment was stopped at the end of the third day. A glance at the following table will show that the action of the hot and the cold water was about the same except that the latter was much slower.

\begin{tabular}{|c|c|c|c|}
\hline SOLCBILITY OF & $\begin{array}{c}\text { Crushed I } \\
1 \mathrm{hr} .\end{array}$ & $\begin{array}{l}\text { IN Cold } \\
2 \text { days. }\end{array}$ & $\begin{array}{l}\text { WATER. } \\
\qquad 3 \text { days. }\end{array}$ \\
\hline $\mathrm{SiO}_{2}, \ldots$ & 1.44 & 13.28 & 15.30 \\
\hline $\mathrm{CaO} \ldots$ & 20.92 & 6.53 & 5.16 \\
\hline $\mathrm{SO}_{3} \ldots$ & 28.26 & 11.08 & 10.68 \\
\hline $\mathrm{MgO}$. & 0.94 & 6.32 & 6.04 \\
\hline $\mathrm{Na}_{2} \mathrm{O}$ & 14.58 & 21.76 & 45.52 \\
\hline $\mathrm{K}_{2} \mathrm{O} \ldots$ & 1.78 & 5.56 & 6.06 \\
\hline Res. in $100 \mathrm{cc} \ldots \ldots$ & 0.4637 & 0.0594 & 0.06 \\
\hline
\end{tabular}

This table also shows percentages in the solid matter in the leaching waters and grams of solid matter in roo cc. Bricks made from the leached rock also developed efflorescence. The major part of the difference between the sum of the constituents recorded in both of the above tables and roo per cent. is made up of $\mathrm{CO}_{2}$ and water of crystallization. In the analyses of the extracts, the water and carbon dioxide varied greatly and were not considered to be of sufficient value to warrant their determination.

In addition to these leaching experiments a number of finished bricks were submerged in water to ascertain if a sort of osmosis could be set up within the brick by which a large percentage of the saline matter would be retained in the interior of the brick. They were submerged for various periods and it was found that it gave only temporary benefit.

Barium carbonate and chloride have been used as a means of removing soluble sodium and potassium compounds, their action being to replace the alkalis and form harmless by-products, the alkali compounds being washed out. However, this method has been used only in the wet process and in cases where the percentage of sodium is much less than ours. As stated above when used in our case it had no effect and altered very little the indefiniteness of the time it would take the various weathering agents to remove the salts by the washing of the rain, evaporation and drawing to the surface of more saline matter.

Upon further investigation it was noticed that those bricks to which lime had been added invariably gave a thick efflorescence, increasing with an increase in the percentage of lime added. Then this same rock has been used as a building stone in its natural state and while it is quite porous has rarely shown any of the above efflorescence when used as such. From these facts it appears that the addition of lime is the cause, at least in part, of the trouble. On the other hand it is absolutely necessary to add some binding material to hold the brick together after it comes from the press. While a brick may be made simply by dampening the ground rock and pressing, the corners chip easily upon handling.

Sirice there seemed to be no chemical means of complete removal or precipitation of the saline matter and addition of lime was partly the cause of the appearance of the film, through its alkaline action on the sodium and potassium and subsequent conversion of these into carbonates, the problem narrowed down to an elimination of the lime, if possible, and the addition of a binding agent which would give a more compact brick as well as one which might have some osmotic properties.

Potassium and sodium are known to occur in basaltic lava in the form of complex silicates. From this fact it is apparent that these silicates are acted upon by the lime, since the bricks after being pressed are run into drying kilns and heated under pressure with steam. The lime, under pressure and at the high temperature of the kiln, reacts with the sodium and potassium in the complex silicates and forms caustic soda and potash as by-products which upon appearance at the surface are converted by the carbon dioxide of the air into carbonates and bicarbonates of the alkalis. If this were true then an elimination of the use of lime as a binding agent should eliminate the trouble. This was done and a small per cent. of cement was used in its stead and the method of drying altered. In this way a more compact brick was obtained and at present writing the alteration is producing decidedly better results.

Thanks are due Mr. W. P. Kelley for valuable suggestions; also for the analyses showing effects of disintegration on lava rock, these analyses being taken from investigations made by him on lava disintegration.

Contribution No. 4, Federal Experiment Station, HONOLULU, HAWAII.

\section{ENAMELS FOR SHEET STEEL. ${ }^{2}$}

BY ROBERT D. LANDRUM.

Received April 4, 1912.

Enamels for sheet steel are boro-silicates of sodium, potassium, calcium and aluminum and are, in every sense of the word, glasses. Such enamels are so compounded that they form a homogeneous, glossy coating on the surface of the sheet steel utensil, which will not be corroded by the acids or alkalies used in cooking and which will resist punishment both by impact and by rapid changes of temperature.

Although an enamel is a glass, the fact that it must adhere to steel and resist the abuse common to cooking utensils makes necessary the addition of other ingredients besides those used in manufacturing ordinary glass. In enamels, ground quartz, flint or sand supply the silica, and feldspar and clay, the alumina. Fluor-

${ }^{1}$ Delivered before the Chemists' Club of Rochester at the University of Rochester, Rochester, New York, April 1, 1912. 
spar or calcite is added to supply the lime and cryolite to render the enamel translucent. Soda ash and pearl ash are fluxes adding sodium oxide or potassium oxide to the product, and borax furnishes the boric anhydride, which adds many desirable qualities, such as greater ductility and elasticity. Sodium or potassium nitrate is used in white enamels and manganese dioxide in dark colored enamels as an oxidizing àgent. Oxide of cobalt is used in enamels which come directly in contact with the steel and adds adhesiveness to this coating.

For producing white enamels, oxide of tin is used; for blue, cobalt; for violet and brown, manganese; for gray, nickel; for green, copper or chromium; for yellow, uranium or titanium; and for red, iron, selenium or gold.

Enameling is still held as a secret art, and the formulas are carefully guarded. Most companies allow very few visitors to go through their plants and some keep their employees in ignorance by various schemes. In one American works, each of the enamel raw-materials is given a number. They are ordered, shipped, kept account of, and stored under their respective numbers, and only those in authority even know what materials are used. In this same factory, employees of one department are not allowed in another and after being employed in one department, a man is barred from employment in any other. Some works have the formula for each enamel divided into two parts, one of which is mixed by one man, the other by a second, and certain proportions of each are then mixed together by a third man. In practically all enameling works, the materials are weighed on a scale, the beam of which is hidden from the laborers, who are also generally of foreign birth and are changed frequently.

The "Black Shape."-The sheet steel which is used for enameled ware is as nearly as is possible free from carbon, silicon, sulphur and phosphorus, and its manganese content is generally about 0.2 per cent. These sheets come in squares and oblongs from 27 to 20 gauge and are circled, stamped and spun with as little heat treatment as possible and with the use of a lubricant that can easily be cleaned off. The ears, handles and other trimmings are, as far as is practical, welded on, as riveted joints are difficult to enamel.

Pickling Process.-The surfaces of the completed steel vessels are thoroughly freed from carbonaceous matter by annealing at a low red-heat and are then pickled in hot dilute acid, thoroughly rinsed in water, and then in weak alkali solution. After a quick drying they are ready to be enameled.

The Enamel.-In the making of an enamel, the various raw-materials are loaded from their respective bins into small cars called "dollies." These are filled to a line which approximates the correct weight, then they are pulled on a scale, the beam of which is hidden from the workman, and the enamel-master indicates whether the loa 1 is light or heavy, and the workmen correct this by shoveling on more or taking some off. When each of the "dollies" is corrected so that the required amount of material for a mix is in it; all are dumped on a large, hard maple floor, the coarser material on the bottom and the finer on the top. This pile is thoroughly mixed by shoveling, and is loaded into an electric elevator, which hoists it to its bin. There is a bin for each different kind of enamel, and a traveling bucket which holds a melt (about I200 pounds) carries the mix to the tank furnaces where it is melted into a liquid glass.

These tank furnaces are regenerative, reverberatory furnaces like those used in the manufacture of glass, and natural gas or crude oil is an ideal fuel for them. However, in the older enameling works, coal is used. directly, and in the later ones producer-gas is used as a fuel. The temperature required for smelting the different enamels varies from $1000^{\circ} \mathrm{C}$. for a glaze to $1300^{\circ} \mathrm{C}$. for a ground coat, and, in most enameling works, pyrometers are installed to assist in controlling these temperatures. Each furnace will give seven or eight melts in twenty-four hours.

After the enamel is melted into a liquid glass, a fireclay plug in the front of the furnace is pulled out and the glowing liquid stream plunges out and is caught in a tank of cold running water. The reaction is terrific and the glass mass is torn and shredded, cracking into small pieces like popcorn, each of which is a myriad of microscopic seams and fissures. This "quenching," as the process is called, toughens the enamel and facilitates the process of grinding which comes next.

The water is drained from the tanks, leaving the "enamel frit." This is shoveled into pans (a certain weight to a pan) and is ready for grinding.

In the mill room, the enamel frit is ground in large ball mills for about thirty hours. These mills are cylindrical, about five feet long and six feet in diameter, and are lined with porcelain bricks. The frit is put into them with fifty per cent. of water and several per cent. of white ball-clay. For the white cover-coat enamels, tin oxide is also added. The mill revolves and the constant impact of the flint stones against the glass particles grinds them to an impalpable powder, which mixes with the water and the clay, forming a mass which has the consistency of rich cream. This is loaded into tanks, where it is allowed to age a week or so.

Application of the Enamel.-From the mill room the enamel is taken to the dipping room, where it is put into tanks that are like large dish-pans. These are sunk into tables, and at each tank a slusher works. The slusher takes the stamped-out steel vessel, which has been thoroughly cleaned, and plunges it into the enamel. When taken out, the wet enamel forms a thin film over the entire surface. By a gentle swinging motion, the excess of enamel is thrown off, and the vessel is placed bottom down on three metal points projecting from a board. Three or four vessels are put on a board; these are placed on racks and when the vessels are thoroughly dry they are carried to the furnace room.

The furnace room contains a long bank of mufflefurnaces and in these the ware is put after drying. The temperature in these furnaces is about $1000^{\circ} \mathrm{C}$. and here the little powdered particles of enamel are 
fused together in a solid glass coating over the vessel, the process requiring from three to five minutes.

Each coat is burned separately. For instance, we have a pudding pan that is to be a three-coat white inside, turquoise-blue mottle outside. It is first dipped in the ground coat ename1, the excess is shaken off and the vessel put on a three-pointed rack and dried. After drying, the enamel stands in little grains all over the surface of the ware, adhering to the metal on account of the raw clay ground with it. At this stage every care must be taken, for a scraping, even of the finger nail, would take off some of the powdered particles of the enamel. This pan is then put into the muffle of the furnace, and the heat fuses all the little particles together, leaving a tight-holding vitreous coating all over the surface of the vessel. This fundamental coating is nearly black, due to the oxides of cobalt and nickel which it contains, and shines with a glass-like luster.

After the vessel has cooled at the ordinary temperature of the room, it is again brought to the slushing room, and here is covered with an enamel-this time a white. It goes through the same process as before, except that a black bead is brushed around the rim. On account of the dark color of the first coat showing through, this second coat, after it is burned, has a gray appearance, and is called the "gray coat" or "first and is dipped into a white enamel, the excess shaken off, and before drying the blue-green enamel is sprayed on the outside.

This spraying process was at one time done by dipping a wire brush into the wet blue-green enamel and the slusher shaking it over the surface of the vessel, causing the blue enamel to fall in little speckles all over the white enamel. In most factories, however, spraying machines, which work on the principle of an atomizer, have been installed. A tank full of the colored enamel stands over the table and the enamel is forced out through a nozzle in a spray by compressed air. The flowing of the enamel is controlled by the foot of the slusher as he holds the vessel in the spray. The vessel is then dried and the coating is fused in the muffle-furnace, the result being turquoise-blue spots on a white background.

The finished ware is assorted into three lots: firsts, seconds, and job lots. Some of the seconds and job lots are fit for redipping. They may have some little spots where the original vessel was not properly white." The vessel is again sent to the slushing room, cleaned and where, on account of the rust or dirt, the

enamel did not adhere. These spots are filed or are held under a sand-blast until the exposed surface is perfectly clean, and then the vessel is covered with another coat of enamel.

There are schemes for saving money in all manufacturing plants, and in the enameling business a large part of the profit comes from the residues. For instance, every bit of enamel is scraped from the tanks and tables, all sweepings from floors are saved, and all the waste water from the various departments is first carried into catch basins, and every few days these are cleaned and the residue, which has settled to the bottom, is taken out. The residues from all these sources are again melted with the proper amount of fluxing material and coloring matter, and this dark-colored enamel is used for coating the cheaper wares.

A German White Enamel.-In order to give an idea of the composition of a white cover-coat frit, such as is used on cooking utensils, and to show the method used by ceramists to calculate its so-called molecular formula, the following enamel, the formula of which is taken from the I $9 \mathrm{II}^{\mathrm{I}}$ edition of the "Taschenbuch für Keramiker,' is used:

Feldspar 38.6 per cent., quartz 19.0 per cent., borax I 5.4 per cent., cryolite II.7 per cent., saltpeter 6.5 per cent., calcite 6.5 per cent., fuorspar I.3 per cent. and magnesium carbonate . .0 per cent.

Enamel Materials,-All the materials used were practically pure except the feldspar, which was a pegmatite of the following composition:

\begin{tabular}{|c|c|c|}
\hline Silica.... & $\left(\mathrm{SiO}_{2}\right)$ & $\begin{array}{c}\text { Per cen } \\
70.66\end{array}$ \\
\hline 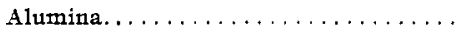 & $\mathrm{Al}_{2} \mathrm{O}_{3}$ & 16.85 \\
\hline Potassium oxide. . . . . . . . . . & $\mathrm{K}_{2} \mathrm{O}$ & 5.93 \\
\hline Sodium oxide $\ldots \ldots \ldots \ldots \ldots \ldots \ldots \ldots$ & $\mathrm{Na}_{2} \mathrm{O}$ & 4.61 \\
\hline $\operatorname{Lime} \ldots \ldots \ldots \ldots \ldots \ldots \ldots \ldots$ & $\mathrm{CaO}$ & 0.52 \\
\hline Carbon dioxide $\ldots \ldots \ldots \ldots \ldots \ldots$ & $\mathrm{CO}_{2}$ & 0.41 \\
\hline Moisture $\ldots \ldots \ldots \ldots \ldots \ldots \ldots \ldots \ldots$ & $\mathrm{H}_{2} \mathrm{O}$ & 1.02 \\
\hline
\end{tabular}

This figures to a "molecular" formula of

$\left.\begin{array}{l}0.45 \mathrm{Na}_{2} \mathrm{O} \\ 0.39 \mathrm{~K}_{2} \mathrm{O} \\ 0.06 \mathrm{CaO}\end{array}\right\} \mathrm{Al}_{2} \mathrm{O}_{3}\left\{\begin{array}{l}7.11 \mathrm{SiO}_{2} \\ 0.34 \mathrm{H}_{2} \mathrm{O} \\ 0.06 \mathrm{CO}_{2}\end{array}\right.$

the molecular weight of which would be 602 .

The other materials used were:

\begin{tabular}{|c|c|c|}
\hline Material. & Formula. & $\begin{array}{l}\text { Equivalent } \\
\text { weight. }\end{array}$ \\
\hline Quartz & $\mathrm{SiO}_{2} \ldots \ldots$ & 60 \\
\hline Borax & $\mathrm{Na}_{2} \mathrm{O} \cdot 2 \mathrm{~B}_{2} \mathrm{O}_{3} \cdot 10 \mathrm{H}_{2} \mathrm{O} \ldots \ldots$ & 382 \\
\hline Cryolite & $2 \mathrm{Na}_{3} \mathrm{AlF}_{6}$, giving $3 \mathrm{Na}_{2} \mathrm{O} \cdot \mathrm{Al}_{2} \mathrm{O}_{3} \cdot 6 \mathrm{~F}_{2} \ldots$ & 420 \\
\hline Saltpeter & $2 \mathrm{~K}_{2} \mathrm{O} \cdot \mathrm{N}_{2} \mathrm{O}_{5} \ldots \ldots \ldots \ldots \ldots \ldots$ & 202 \\
\hline Calcite & $\mathrm{CaO} \cdot \mathrm{CO}_{2} \ldots \ldots \ldots \ldots \ldots \ldots \ldots$ & 100 \\
\hline Fluorspar & $\mathrm{CaF}_{2}$, giving $\mathrm{CaO} \cdot \mathrm{F}_{2}, \ldots \ldots \ldots \ldots$ & 78 \\
\hline Magnesium carbonate & $\mathrm{MgO} \cdot \mathrm{CO}_{2} \ldots \ldots \ldots \ldots \ldots \ldots \ldots$ & 84 \\
\hline Feldspar & $\ldots \ldots \ldots \ldots$ & 602 \\
\hline
\end{tabular}

THE ENAMEL.2

\begin{tabular}{|c|c|c|c|c|}
\hline Batch Mix. & $\begin{array}{l}\text { Per cent: } \\
\text { used. }\end{array}$ & M. W. & $\begin{array}{l}\text { Molecular } \\
\text { equivalent. }{ }^{3}\end{array}$ & $\mathrm{Na}_{2} \mathrm{O}$. \\
\hline Feldspar.............. & 38.6 & 602 & 0.0641 & 0.0288 \\
\hline Quartz............... & 19.0 & 60 & 0.3167 & . \\
\hline Borax............... & 15.4 & 382 & 0.0403 & 0.0403 \\
\hline Cryolite. . . . $\ldots \ldots \ldots$ & 11.7 & 420 & 0.0279 & 0.0837 \\
\hline Saltpeter. . . . . . . . . & 6.5 & 202 & 0.0322 & $\ldots$ \\
\hline Calcite. ............. & 6.5 & 100 & 0.0650 & $\ldots$ \\
\hline Fluorspar............. & 1.3 & 78 & 0.0167 & $\ldots$ \\
\hline Magnesium carbonate... & 1.0 & 84 & 0.0119 & . \\
\hline Total. & . . & . & $\ldots$ & 0.1528 \\
\hline
\end{tabular}

\begin{tabular}{|c|c|c|c|c|c|c|}
\hline $\mathrm{K}_{2} \mathrm{O}$ & CaO. & MgO. & $\mathrm{Al}_{2} \mathrm{O}_{3}$. & $\mathrm{SiO}_{2}$ & $\mathrm{~B}_{2} \mathrm{O}_{3}$. & $F_{2}$. \\
\hline .0250 & 0.0038 & . & 0.0641 & 0.4558 & . & . \\
\hline$\cdots$ & . & . . & . & 0.3167 & . & $\ldots$ \\
\hline .. & . & . & . & . & 0.0806 & .. \\
\hline . & . & . & 0.0279 & . & . . & 0.1674 \\
\hline .0322 & . & .. & $\cdots$ & . & . & . \\
\hline . & 0.0650 & .. & . & . & . & . \\
\hline$\cdots$ & 0.0167 & . & . & . & . & 0.0167 \\
\hline . & $\cdots$ & 0.0119 & . & $\cdots$ & . & $\cdots$ \\
\hline 572 & 0.0855 & 0.0119 & 0.0920 & 0.7725 & 0.0806 & 0.1841 \\
\hline
\end{tabular}

"A Comparison of Ten White Enamels" in the Trans. Am. Ceramic Soc., Vol. XIV.

${ }^{3}$ Molecular equivalent equals per cent. used divided by $M$. W. 
The above total corresponds to the following molecular formula of enamel:

$\left.\begin{array}{l}0.497 \mathrm{Na}_{2} \mathrm{O} \\ 0.186 \mathrm{~K}_{2} \mathrm{O} \\ 0.278 \mathrm{CaO} \\ 0.039 \mathrm{MgO}\end{array}\right\} 0.299 \mathrm{Al}_{2} \mathrm{O}_{3}\left\{\begin{array}{l}2.513 \mathrm{SiO}_{2} \\ 0.262 \mathrm{~B}_{2} \mathrm{O}_{3} \\ 0.599 \mathrm{~F}_{2}\end{array}\right.$

RESEARCH IAABORATORY,

Lisk Manufacturtng Co., Ltd.,

Canandaigua, N. Y.

THE PRODUCTION OF EXCESSIVE HYDROGEN SULFID IN SEW AGE DISPOSAL PLANTS AND CONSEQUENT DISINTEGRATION OF THE CONCRETE. ${ }^{1}$

By WILLIAM M. BARR AND R. E. BUchaNAN. Received February 15, 1912.

It is well known to those who are familiar with the operation of the septic tank that in the chambers of such tanks, which operate in the absence of light and air, the bacteria produce, in the decomposition of the organic matter of the sewage, quantities of reducing gases. Among the decomposition products is observed more or less hydrogen sulfid gas, resulting in most cases from the decomposition of organic sulfur compounds existing in the sewage. In most tanks of this character the amount of hydrogen sulfid thus liberated is not sufficiently large to cause complaint from excessive odors or to account for the conditions in certain tanks observed by the writers.

Attention was first called to the disintegration of cement mortar in concrete resulting from sewer gases, by Olmstead.2 The case observed by him occurred in the outfall sewer for Los Angeles, built in 1895 . This resulted from the holding back of the sewage in inverted siphons in this sewer, forming, in principle, a septic tank. Beyond this point the neat cement mortar was badly disintegrated and it became necessary to reconstruct the walls and roof of this portion of the se:wer. It was observed that the disintegration resulted from the formation of sulfuric acid upon the walls and roof, which attacked the cement, giving calcium sulfate as the final product. It was also observed that the amount of sulfuric acid formed appeared to be too large to have been produced by the organic sulfur compounds in the sewage proper. It was also suggested that the only possible sources of this excessive amount of sulfur were the oil wells and the sulfur which is always present in small quantities in the normal sewage. The report does not indicate that the source of these sulfur compounds was definitely located.

The case of a septic tank in England where a condition similar to the one cited above existed has been reported by Dunn, 3 but no attempt is made to show any relation between this condition and the character of the water supply.

As early as November, r908, one of us visited the sewage disposal plant of the Inebriate Hospital at Knoxville, Iowa, and observed the following conditions: The concrete composing the roof and walls above the high water line in the dosing chamber was rapidly disintegrating. The under surface of the roof

\footnotetext{
${ }^{1}$ From a Bulletin of the Eng. Expt. Sta., Iowa State College.

2 Eng. News, 44, 317.

3 Cement Eng. News, 22, 10.
}

was found to be decomposed to a depth of $2 \mathrm{~cm}$. Quantities of free sulfur were deposited upon the walls, and the calcium compounds of the cement were found to have been converted near the surface into crystals of gypsum. Large quantities of hydrogen sulfid were given off when the dosing chamber discharged, causing complaint of foul odors by neighbors and residents at the hospital. At a later date a similar condition was observed in the septic tank receiving the sewage of the city of Grinnell, Iowa.

In both these cases various measures have been tried to prevent the formation of excessive odors and decomposition of the concrete. A water-softening plant was installed at the Knoxville institution, thinking this might improve conditions, but, except for making the water more desirable for domestic purposes, nothing was achieved. Frequent cleaning of the tank and disinfecting at the time of cleaning did not materially improve conditions.

During the progress of this investigation our attention was called to the septic tank at the State Hospital at Mt. Pleasant, Iowa, and before visiting the place, an analysis of the water supply caused us to predict the condition existing there. A visit showed the septic tank to be in much the same condition as those first studied.

The object of this investigation was to determine the cause of the conditions above noted and to determine whether bacteria were in any measure responsible for the changes, or whether they were purely of a chemical nature. The various observations made by us, together with analyses of the water supplies and the sewage, seemed to point to some definite relationship existing between the compounds of sulfur in the water supply and the formation of excessive hydrogen sulfid, with the consequent formation of sulfuric acid on the walls of the tank.

This was used for a working hypothesis for the following reasons:

First.-The water supplies in the cases observed were found to have an unusually high content of sulfates.

Second.-The odor of hydrogen sulfid was, in all cases, very pronounced about the dosing chamber.

Third.-Free sulfur was found floating on the surface of sewage which had been standing for some time, and quantities of free sulfur were deposited on the walls in various parts of the septic tank.

Fourth.-An abundance of sulfur bacteria was evident upon microscopic examination.

Fifth.-The disintegrating concrete showed much greater amounts of sulfate than the unaffected concrete, and as already stated showed crystals of gypsum on microscopic examination.

A large proportion of proteins contain a considerable percentage of sulfur. When such compounds are decomposed in the absence of oxygen, the sulfur makes its appearance for the most part in combination with hydrogen as hydrogen sulfid. Inasmuch as proteins and the products of hydrolytic cleavage are generally to be found in sewage, it is to be expected that a certain amount of hydrogen sulfid will be de- 